\title{
Spatial Change of Resettlement Area and Location Vulnerability
}

\author{
Winny Astuti ${ }^{1, *}$, Paramita Rahayu ${ }^{1}$, and Erma Fitria Rini ${ }^{1}$ \\ ${ }^{1}$ Urban and Regional Planning Department, Universitas Sebelas Maret Surakarta Indonesia
}

\begin{abstract}
This paper analyzes the Change of Livelihood of Resettlements Area in Mojosongo after being a destination area of a resettlement program. The program resettled 453 households devastated from the flooding area of River Bank of Bengawan Solo. Many scholars argue that the resettlement program commonly situate people into a vulnerable situation, especially in the early stage of post resettlement. With regard to this common argument, spatial analysis was conducted to describe spatial change of the resettlement area before implementation of the program (2006); in the middle of the implementation of programmes (2013) and in the current situation (2018). Interviews have been conducted to Head of Housing, human settlements and Land Government unit, and head of the community. This results show that this resettlement program partly creates a vulnerable situation. However, due to the commitment of the local government, and integrated program have been conducted along the resettlement process. This approach is able to accommodate the community's interests and government program. Such integration is able to provide infrastructure and social services that in accordance to community's need and interests. Therefore, it is expected to reduce the risk of community to be exposed in a vulnerable situation after the resettlement program.
\end{abstract}

Keywords: Resettlement; vulnerability; spatial change; livelihood

\section{Introduction}

Agenda of 11 th of SGDs states that Make cities and human settlements inclusive, safe, resilient and sustainable [1]. This agenda sets a propose for cities to be socially inclusive, affordable, environmentally sustainable facing climate change and résilience to all risk and hazardous [2]. Social vulnerability of place is contributed by place inequalities, which influence and shape susceptibility of community to harm or to be able to respond [3]. Most resettlement program has been usually conducted in emergency condition, where there is no other solution choices (World Bank, 1990). Most reasons are related to eviction of people caused by a big scale of infrastructure development, city beautification where slums have been considered as handicapped of urban aesthetic. This is supported by low government procedure and regulation in protecting people from eviction [4].

* Corresponding author: winnyast64@gmail.com 
The research was based on the fact that in 2006 there was 1571 squatter settlements occupied riverbank area of the Bengawan Solo River, located in the flood hazardous location area. In 2007, in flooding disaster all squatter settlements there were all have been impacted. The government of Surakarta initiated the Resettlement program for resettling people from a squatter settlement into residential areas conformed to the Spatial Plan. As stated in the Major Regulation no 15/ 2007, the resettlement's Program required formulation of a community working group called POKJA (Kelompok Kerja $=$ Working Group), The POKJA had a role for mediation of community to be able to communicate with the local government, Most of squatter residents have been resettled to Kelurahan Mojosongo as a new residential area in the north of Surakarta. In 2012 the government of Surakarta has been successfully in resettling 453 households by implementing communitybased development to mostly to Mojosongo and some of them has been resettled to Sukoharjo Regency. After implementation of the program, there have involved cross sectoral institutions for supporting area of resettlements with several public services such as water supply system, road provision; land tittle certification; job creation and others

After10 year implementation of resettlement program, especially Kelurahan Mojosongo has been indicated Spatial Change, related to the change of land utilization, accessibility, infrastructure development, livelihood profile. This research explored spatial change livelihood profile of the resettlement area in Mojosongo Village in 2006 (before the resettlement program implemented); 2013 (after 5 years implementation of the program) and in 2018 (after 10 years after implementation of the program). This scrutinized whether spatial change has contributed to social vulnerability of location. The research questions were firstly, to what extend the Resettlement Program affects spatial change of the region and secondly, to what extend the programs supporting Resettled community to reduce their vulnerability

\section{Research Method}

\subsection{Study Area}

This research identified the change of land use in Kelurahan Mojosongo as one Kelurahan in Surakarta, which were mostly squatter settlers along riverbank areas of the Bengawan Solo River have been displaced in this location areas. As destination areas of a resettlement program distributed into 2 regencies: firstly in Surakarta, there are 12 spot areas of resettlement mostly in Kelurahan Mojosongo and secondly, 4 spots, areas of resettlements located in Sukoharjo regency. Table 1 shows the distribution area of resettlement

Table 1. Distribution Area of Resettlement

\begin{tabular}{|c|c|c|c|c|}
\hline \multirow{2}{*}{$\begin{array}{l}\mathbf{N} \\
\mathbf{o}\end{array}$} & \multirow{2}{*}{$\begin{array}{l}\text { Place of } \\
\text { origin }\end{array}$} & \multicolumn{2}{|l|}{ Destination Area } & \multirow{2}{*}{$\begin{array}{c}\text { Total } \\
\text { housing } \\
\text { unit }\end{array}$} \\
\hline & & Name of Village/Sub district/ Regency & Name of area & \\
\hline \multirow{3}{*}{1} & \multirow{3}{*}{ Pucangsawit } & \multirow{3}{*}{ Mojosongo/ Jebres/ Surakarta } & Ngemplak Sutan & 112 \\
\hline & & & Solo Elok & 89 \\
\hline & & & Kedung Tungkul & 18 \\
\hline \multirow{5}{*}{2} & \multirow{5}{*}{ Jebres } & \multirow{4}{*}{ Mojosongo/ Jebres/ Surakarta } & Mertoudan & 25 \\
\hline & & & Kaplingan & 22 \\
\hline & & & Mipitan & 11 \\
\hline & & & Sabrang Lor & 24 \\
\hline & & Jebres/ Jebres/ Surakarta & Jebres Tengah & 13 \\
\hline 3 & Sewu & Mojosongo/ Jebres/ Surakarta & Tawang Sari & 13 \\
\hline 4 & Sangkrah & Sangkrah/ Sangkrah/ Surakarta & Sangkrah & 9 \\
\hline
\end{tabular}




\begin{tabular}{|c|l|l|l|l|}
\hline \multirow{2}{*}{} & \multirow{2}{*}{ Laban/ Mojolaban/ Sukoharjo } & Laban & 5 \\
\cline { 3 - 4 } & & Mojosongo/ Jebres/ Surakarta & Gadingan & 53 \\
\cline { 3 - 4 } & & Boyolali & Kepuhsari & 13 \\
\hline 5 & Semanggi & Laban/ Mojolaban/ Sukoharjo & Meletan & 8 \\
\hline 6 & Joyosuran & Parangjoro/ Grogol/Sukoharjo & Soroyudan & 31 \\
\hline \multicolumn{2}{|c|}{ Total } & Parangjoro & 7 \\
\hline
\end{tabular}

Sources: Bapermas, 2007

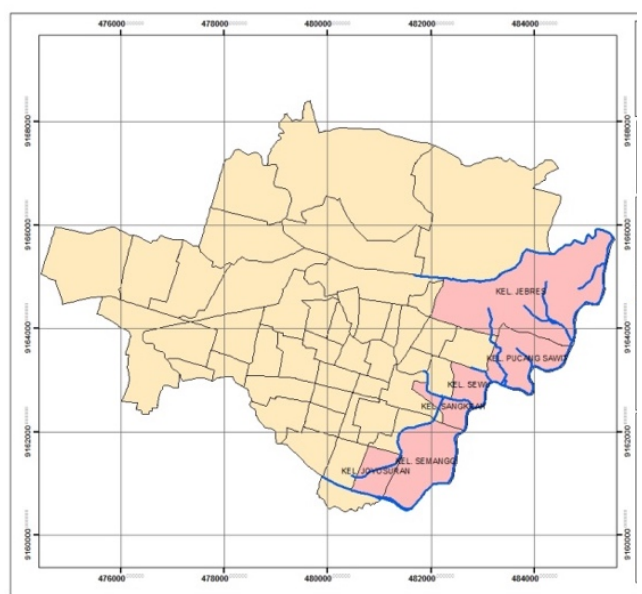

Fig. 1. Map of Location of Place of origin of settlers in 6 Kelurahan in Riverbank Area Sources: Bella, 2014

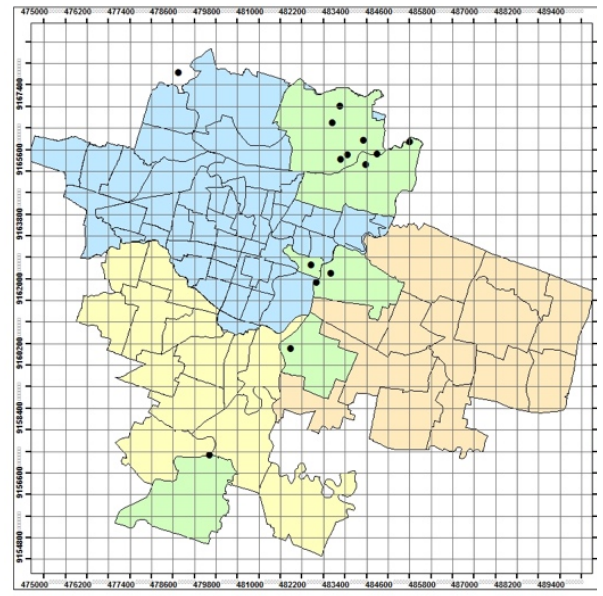

Fig.2. Map of Distribution of Location of Resettlement Areas. Sources: Bella, 2014

Figure 1 shows place of origin of the settlers in 6 Kelurahan along the riverbank of the Bengawan Solo River. As shown in figure 3 and figure 4, the area has been always impacted by flooding disaster every year. Resettlement program was implemented in order to move people to other more safe and livable residential area, while the previous area was planned for the urban forest

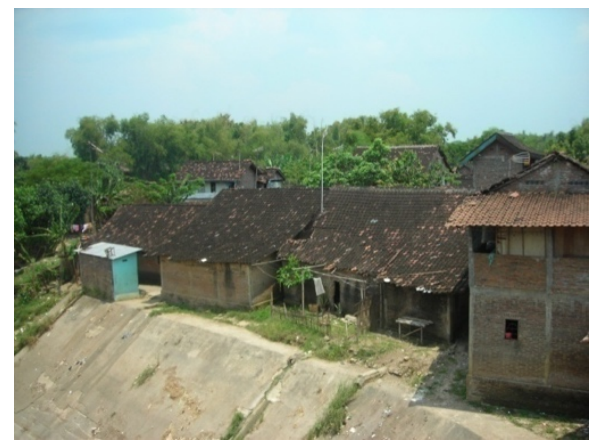

Fig. 3. Condition of Residential Area along River Bank Area of Bengawan Solo River Photo Author: Astuti, 2011

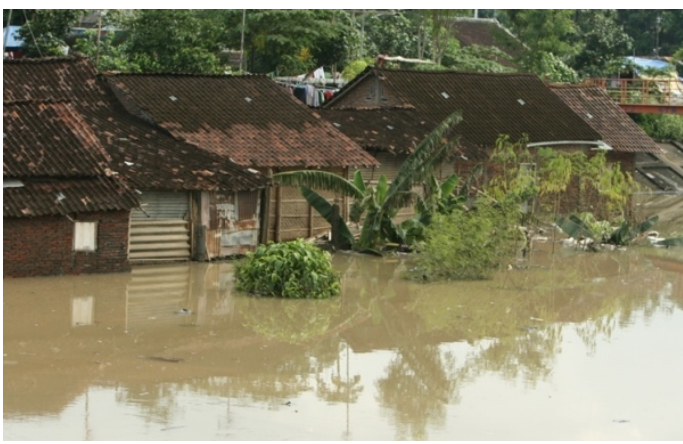

Fig. 4 Condition of Residential Area along River Bank Area of Bengawan Solo River Photo Author: Surakarta Government 2008 


\subsection{Research Approach}

This research used Livelihood Approach in the analysis of resettlement. Some frameworks were analyzed using Neighborhood Sustainable Livelihood Framework (SLF) (Carney, 1998, 1999; Scoones, 1998), the Framework for Thinking about Diverse Rural Livelihoods (Ellis, 2000), Bebbington's (1999) Capitals and Capabilities Framework, and the UNDP's (1999) Sustainable Livelihoods Diamond. These approach tried to integrate community assets, constraints, community capacity to analyze livelihood conditions in the frameworks of space and time (CHIMHOWU and HULME, 2006)

According to Ashley and Carney, 1999, sustainable livelihood approach is the instrument to improve the quality and relevance of the program designed to poverty reduction. He argued that SL, which should be committed to poverty eradication should be; 1) People centered; 2). Responsive and participatory; 3) multilevel; 4) conducted in partnership; sustainable in 4 dimensions: economic, institutional, social, environment; and dynamic. This research used the Sustainable Livelihood approach, which was included in case study research using evaluation and monitoring research of SL by conducting Monitor a range of livelihood impacts -where SL analysis can help identify the priority second round effects - both positive and negative - to be monitored (e. g. Impact on other assets, activities, structures and processes). Socially differentiated monitoring (Ashley and Carney, 1999)

\subsection{Data Gathering}

Data were gathered through several collections: 1)Main data was gathered through field observation related to the aspects of Land use (built up and non built up area); accessibility, infrastructure provision and transportation; 2) Interview survey has been conducted to several institutions and Key persons as followes: Government Unit of Housing, Human Settlements and Land of Surakarta City; Government units of Public Works and Spatial, Planning and Head of community units in Resettlements Area, and 3) Focused Groups Discussion .Figure 5 shows Sustainable Livelihoodl Analysis that was conducted to show spatial change of the resettlement's area, how were the vulnerability of the area and how were the community responses to reduce the vulnerabiliy of the area

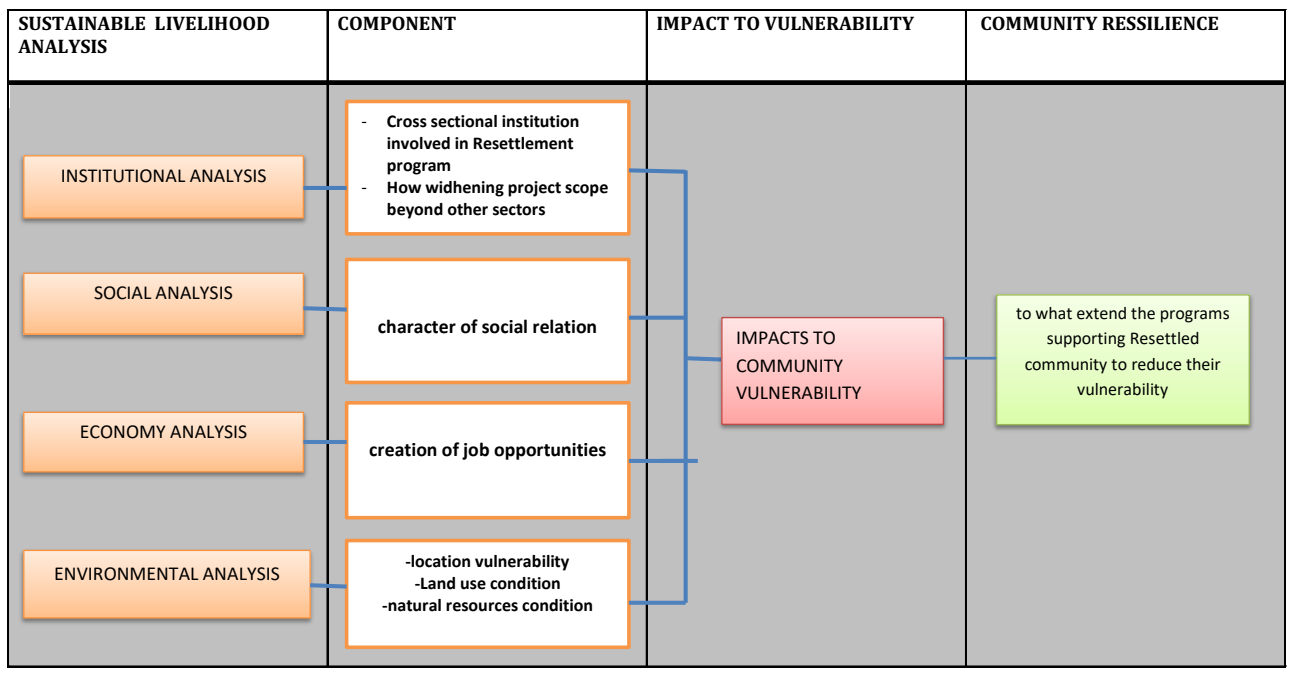

Fig 5. Framework of Analysis of the Research 


\section{Results and Discussion}

\subsection{Spatial Change affected by Resettlement Program}

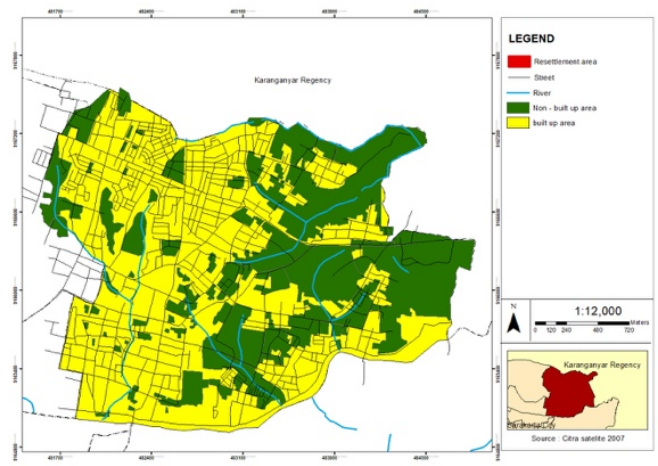

Fig. 6. Land Use of Resettlement Area in Kelurahan Mojosongo before Implementation of Resettlement 2006 (Sources: Field Survey, 2018)

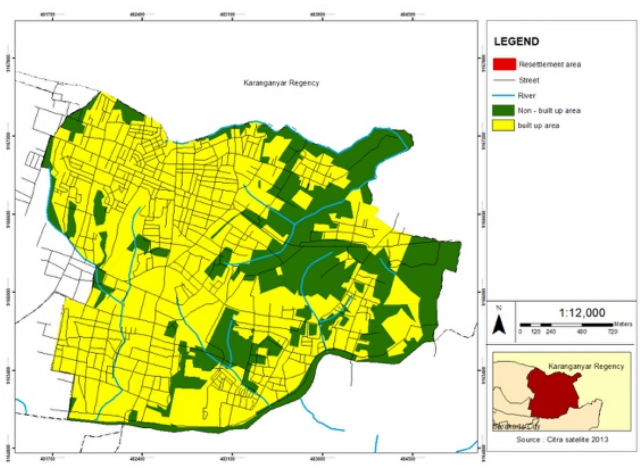

Fig. 7. Land Use of Resettlement Area in Kelurahan Mojosongo 2013 after Implementation of Resettlement program

Sources: Field survey, 2018

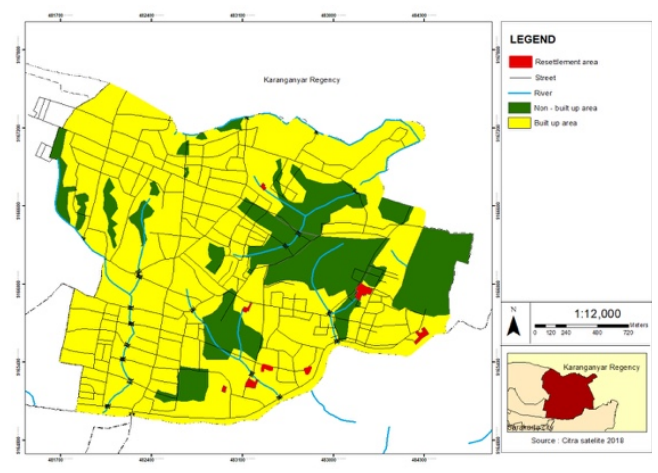

Fig 8. Land Use of Resettlement Area in Mojosongo after 10 years Implementation of Resettlement Program. Sources: Field Survey, 2018

Degree of development of the built environment in one factor indicating vulnerability [3]. The table shows the change of characteristics of the area from 2006 to 2013 and 2018 related to the domination of built and non built area. Figure 5,6,7 shows the reduced non -built up area during 10 years implementation of the resettlement program. It means that after 10 years implementation of resettlement program, there has been spatial change in terms of increasing the build up areas.

Table 2. Chacateristics of Resettlements Area in 2006, 2013 and 2018

\begin{tabular}{|c|c|}
\hline Year & Characteristics of Resettlements Area \\
\hline 2006 & $-\quad \begin{array}{l}\text { The Mojosongo Village before becoming destination areas of the resettlement } \\
\text { program. The area is located in a hilly location with topography more than } 15 \% \text { in }\end{array}$ \\
& $\begin{array}{l}\text { some part of the area } \\
\text { - However the area of resettlement is located in a safe area from flooding hazards }\end{array}$ \\
& $-\quad$ Most of the location is cultivated land with limited access of water supply. The \\
\hline
\end{tabular}




\begin{tabular}{|c|c|}
\hline & $\begin{array}{l}\text { sources of clean water has only found through artists wheels } \\
\text { - Percentage of built area and non built area is } 39,441 \%: 60,559 \%\end{array}$ \\
\hline 2013 & $\begin{array}{l}\text { - All squatter settlers of } 349 \text { households have been resettled from } 4 \text { kelurahan located } \\
\text { on the riverbank to Kelurahan Mojosongo (see table 1). Some part of areas have been } \\
\text { developed followed by provision of transportation mode and routes to this area. } \\
\text { - The water supply system has been provided by PDAM (Local Government Cosporate } \\
\text { of Water supply) } \\
\text { - Percentage of built area and non built area is } 42.9 \%: 57.1 \%\end{array}$ \\
\hline 2018 & $\begin{array}{l}\text { - Characteristics of resettlement destination areas after } 10 \text { years implementation of the } \\
\text { program have been developed with } 74.453 \% \text { of built up area.. By public and private } \\
\text { partnership, the location has been provided by infrastructure such as from PDAM as } \\
\text { well as communal domestic waste water treatment form PDAM } \\
\text { - Housing construction has been developed by self-help development in line with the } \\
\text { development of economic condition of the community. } \\
\text { - Most of people are doing the same economic activities with their economic activities } \\
\text { before resettlement. However, some houses have been developed as home-based } \\
\text { enterprise by development of income generating activities in their house such as } \\
\text { shops, }\end{array}$ \\
\hline
\end{tabular}

\subsection{Location vulnerability}

\subsubsection{Low Livability of Location}

Resettlement leads to risks to livelihood security, and the socioeconomic impacts of resettlement of communities imply increased vulnerability and perhaps maladaptation that increases vulnerability [5].

Resettlements policy in Surakarta was purposed for resettling people from the hazardous flooding area as a part of increasing access of informal settler to appropriate land and housing for poverty alleviation strategy. Resettlement Program has moved out people from illegal settlements along the riverbank area of the Bengawan Solo River to Residential Area conformed to Spatial Plan of Surakarta as Residential Area. The new Area of resettlement is saved from flooding disaster, as well as a parcel of land with security of tenure. However, due to a limited funding from the government, the new location affords for resettled people was located in low quality of land for residential area. In spite of located in a hilly location, with some part of area in land topography with more than $15 \%$ degree, the new location of resettlement has been remotely far from transportation accessibility (see figure 8). At the beginning of resettlement, access to water supply has also been limited where the only sources of water has only found from artists wells. After 10 years living there, the public Water supply (PDAM) has been provided at this location. This reduced vulnerability of location 

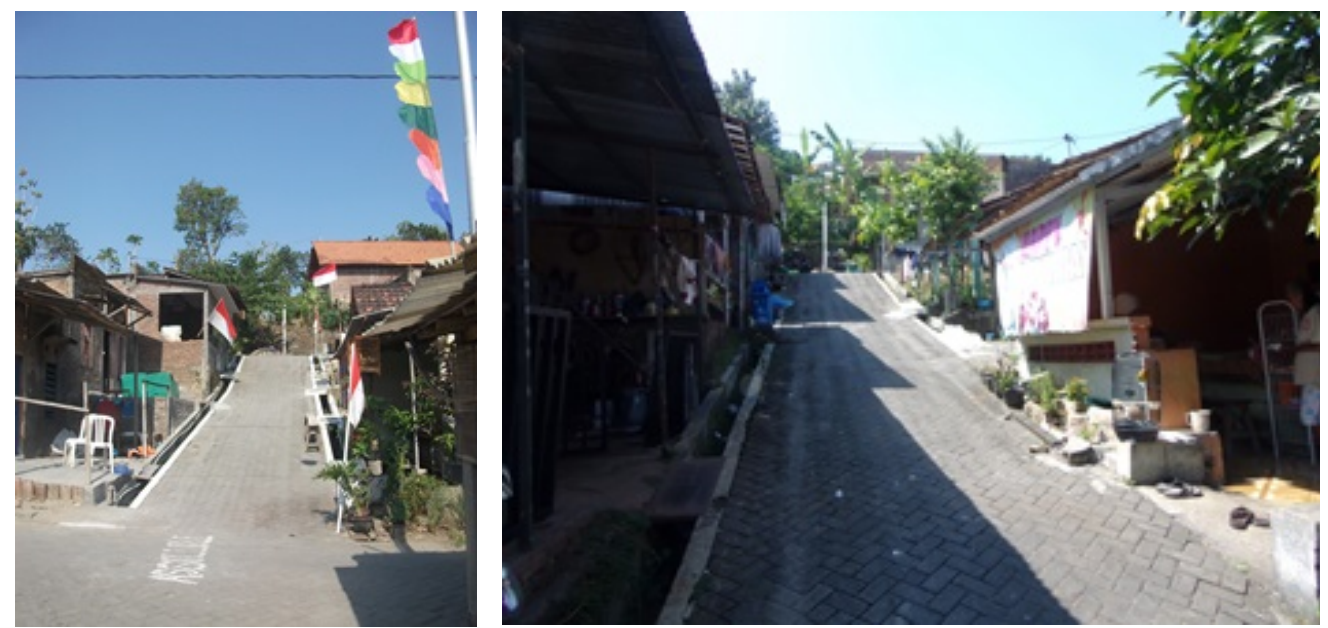

Fig.9. Low quality of Location of resettlement in hilly and topographical area (Photo author: Astuti, W, 2012 and 2018)

\subsubsection{Displace Location of Job Opportunities}

From the interview to community leader, it was found that in the early stage of resettlements, the people felt displaced from the previous job opportunities, which the jobs were mostly located close to their previous residential areas. However, by the time, where the accessibility of location has been increased by supporting of some efforts and programs from the government, the community has been adapted the situation by creating new job opportunities, which are usually in the form of home-based enterprises in their new own houses in the resettlement area.
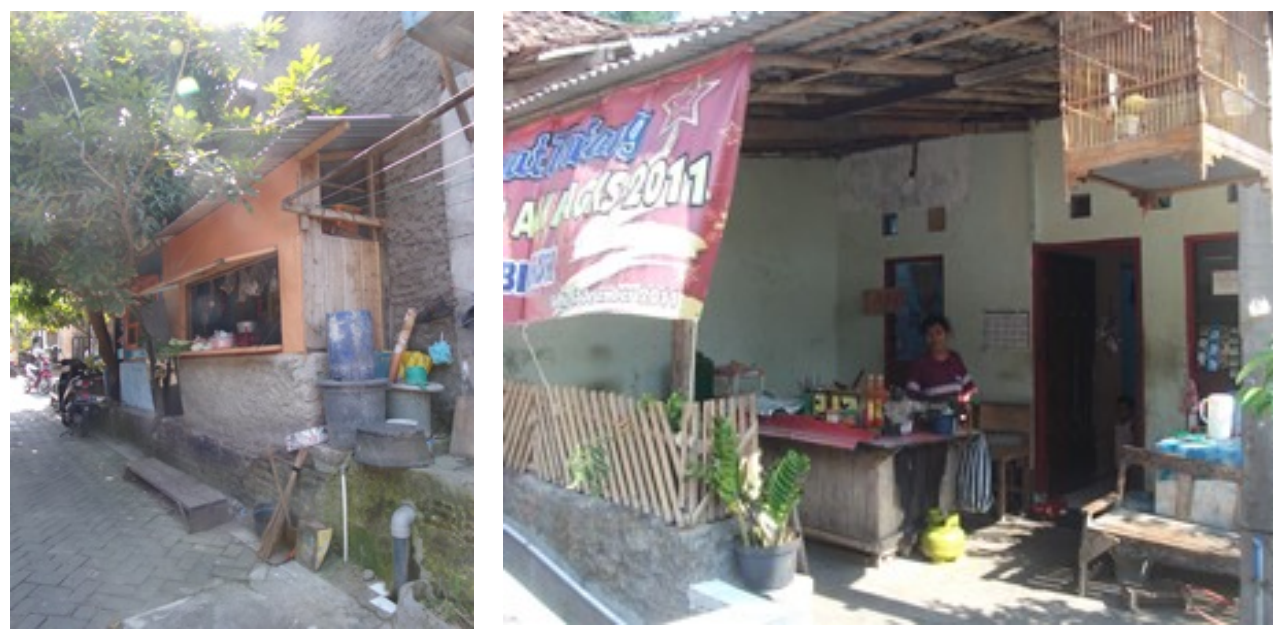

Fig 10. Job creation has been developed in the new area in the resettlement area (Photo author: Astuti, 2012 and 2018)

\subsubsection{Limited Access to public services}

According to cutter et al, 2003 One factor of sustainability index is Infrastructure Dependence especially transportation and communication. In resettlements Area of Mojosongo there was a limited access of transportation to the area. Only $20 \%$ people have 
access to public transportation routes, which was in the distance range of below 200 meters [6]. Apart from that, due to hilly and infertile location of Mojosongo, the condition of water supply was below the standard quality. The only sources of water supply were from artists wells.

However, this situation has been changed by the policy of the local government to provide most of basic services needed by the resettled households. Table 3 shows that due to integrated planning initiated by the Surakarta government, some infrastructure was provided by the Department of Public Work Central Java for provision drainage. Whether the construction of access road to the location and other public services was serviced by the Local Government Unit of Public Works [7]. Apart from that, electricity has been provided by PLN as well as clean water supply was done by PDAM. Collaborative planning in resettlements Program has overcome the problems of location vulnerability faced by the new settlers.

Table 3. Role of Institution integrated in the Resettlements Program

\begin{tabular}{|c|c|c|}
\hline No & Supported Institutions & Role of Institution \\
\hline \multicolumn{3}{|c|}{ National/International } \\
\hline 1 & $\begin{array}{l}\text { Coordinator Ministry of } \\
\text { CommunitWelfare (Kemenko Kesra) }\end{array}$ & $\begin{array}{l}\text { Awarding grants for land purchase for new location } \\
\text { of resettlement from Nationl Public Budget }\end{array}$ \\
\hline 2 & UN - Habitat & $\begin{array}{l}\text { Grant for Warranty for obtaining Hosuing } \\
\text { Mortagage from Bank }\end{array}$ \\
\hline 3 & $\begin{array}{l}\text { Main Office of Bengawan Solo River } \\
\text { Area (BBWSBS) }\end{array}$ & $\begin{array}{l}\text { Study of DAS Bengawan Solo related to Spatial } \\
\text { Plan for Riverbank Area after leaving by squatter } \\
\text { settlers. }\end{array}$ \\
\hline \multicolumn{3}{|c|}{ Province } \\
\hline 4 & Public Works of Central Java & Provision of Urban Infrastructure \\
\hline \multicolumn{3}{|c|}{ Local Government } \\
\hline 5 & Legislative of Surakarta City & $\begin{array}{l}\text { Approvement of public budget for Housing } \\
\text { construction Grant }\end{array}$ \\
\hline 6 & Bureau of Community Empowerment & Leading sector of Program implementation \\
\hline 7 & $\begin{array}{l}\text { Government Unit of Cleanleness and } \\
\text { City Park (DKP) }\end{array}$ & $\begin{array}{l}\text { Provision of Community Parks in Resettlements } \\
\text { Areas. }\end{array}$ \\
\hline 8 & $\begin{array}{l}\text { Government Unit of Public Works } \\
\text { (DPU) }\end{array}$ & $\begin{array}{l}\text { Provision of Local Road, Public services and } \\
\text { transportation to location of resettlement }\end{array}$ \\
\hline 9 & $\begin{array}{l}\text { Government Unit of Urban Planning } \\
\text { (DTK) }\end{array}$ & Preparation of site plan of resettlement area \\
\hline 10 & Bureau of Planning and Development & Coordination of the program \\
\hline 11 & Notaries/PPAT & Land Tenure certification and Law consultation \\
\hline 12 & Bureau of Environment & $\begin{array}{l}\text { Environmental Impact Assessment of resettlement } \\
\text { area }\end{array}$ \\
\hline 13 & National Electricity & Provision of Electricity \\
\hline 14 & $\begin{array}{l}\text { Local Corporate of Water Supply } \\
\text { (PDAM) }\end{array}$ & Provision of water supply and hydrant \\
\hline 15 & $\begin{array}{l}\text { Bureau of Local Public Services } \\
\text { (BLUD Griya Layak Huni) }\end{array}$ & $\begin{array}{l}\text { Providing warranty for applying Home ownership } \\
\text { loans to financal institution (BANK) }\end{array}$ \\
\hline 16 & $\begin{array}{l}\text { National Agrarian Bureau of } \\
\text { Surakarta }\end{array}$ & Land Tenure Certification \\
\hline 17 & Kelurahan and Kecamatan & Technical Assistant in implementation of program \\
\hline
\end{tabular}

Sources: Interview with Bapermas and Pokja, 2012 


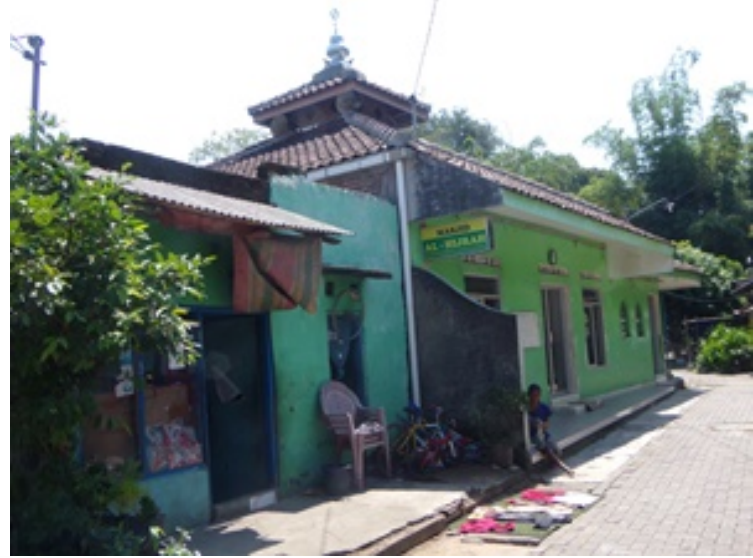

Fig 11. Provision of religion Facility in Resettlements Area (Photo author: Astuti, et al, 2018)

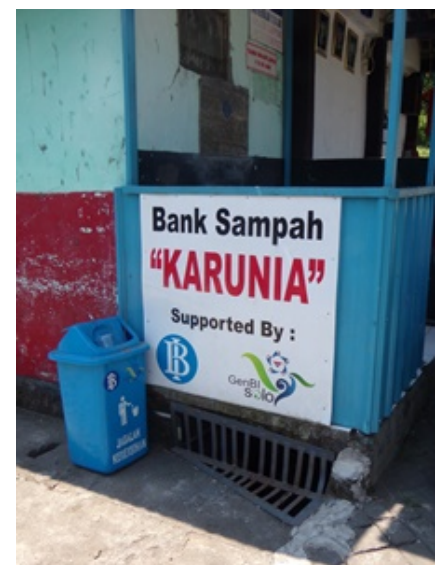

Fig 12. Provision of Garbage Bank supported by Bank Indonesia (Photo author: Astuti, et al, 2018)

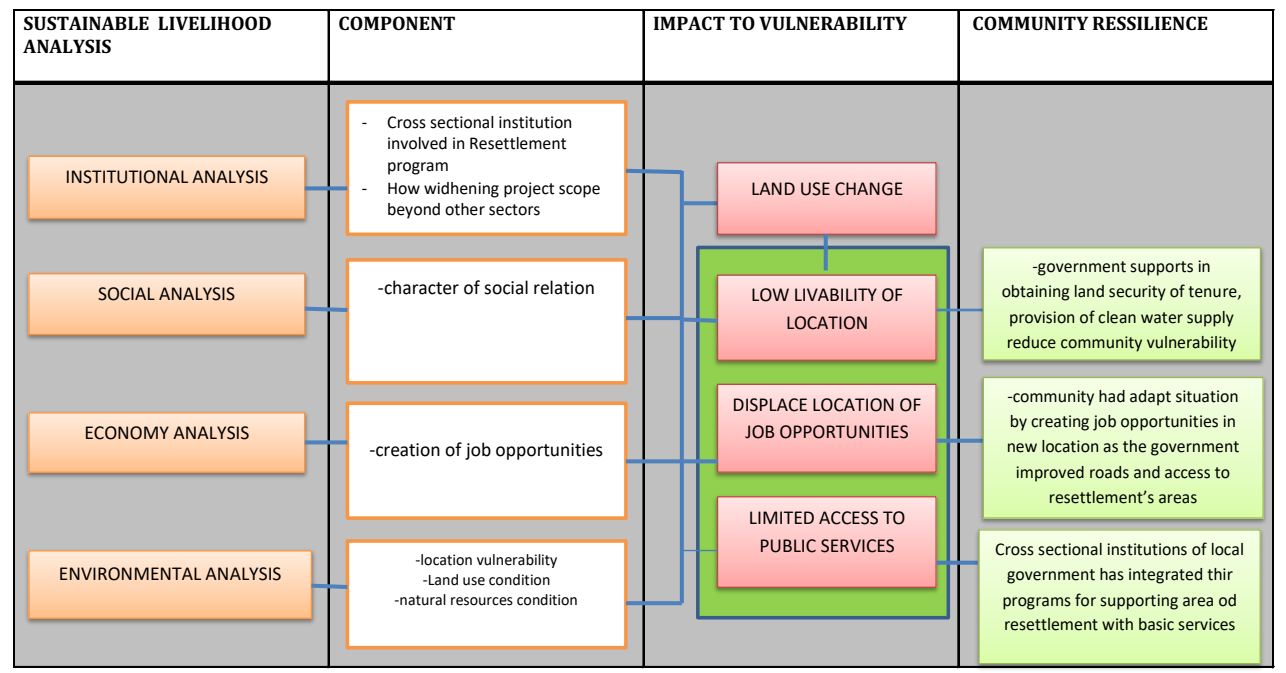

Fig 13. Community and government efforts to reduce vulnerability of Resettlement's Area

\section{Conclusion}

Resettlement Government Program tends to bring people in a vulnerable situation, especially in the early stage. This relates to location vulnerability as well as socioeconomic vulnerability, such as low quality of location, lacking of infrastructure and public services, displacement of job opportunities and social displacement. In the study area of Resettlement of squatter settlement of riverbank area of Bengawan Solo Surakarta to Kelurahan Mojosongo, in the early stage of Resettlement, even though the new residential area legally conforms to Spatial Plan of Surakarta as Residential area and securely safe from flooding disaster, the people have still lived in vulnerable locations. The Resettlements location was situated in a hilly area lacking of clean water supply, limited access of transportation mode and routes. Some settlers felt displaced from previous jobs. 
However, from Sustainable Livelihood analysis, it was found that the community reduced the vulnerable situation with job creation in a new location, increased social interaction in the new location. By cross sectional institutions of local government integrating their programs to support basic services in the resettlement areas, these helped people cope with the vulnerable situation and lead to sustainable livelihoods.

\section{References}

1. UNDP. (2014) Output Document of the Open Working Group on Sustainable Development Goals, 2014

2. A. Revi ,Aromar (2013). The Urban Opportunity: Enabling Transformative and Sustainable Development. Background Paper for the High Level Panel of Eminent Persons on the Post-2015 Development Agenda. Prepared by the Sustainable Development Solutions Networks Thematic Group on Sustainable Cities

3. SL. Cutter, B.J. Borruf, W.L.Shirley, WL. (2003). Social Vulnerability to Environmental Hazards. SOCIAL SCIENCE QUARTERLY, Volume 84, Number 2, June 2003

4. ESCAP and UN Habitat (2009) Planning sustainable cities: Policy directions UN Habitat - Global report on human settlements

5. T. Xue and S. Rogers (2015). Resettlement and climate change vulnerability: Evidence from Rural China. Global Environmental Change 35 (2015) 62-69

6. N. Bella (2014). Impact of Physical Change toward Change of community Welfare in Resettlements Program of Bengawan Solo Riverbank Surakarta City. Universitas Sebelas Maret Indonesia

7. W. Astuti, 2012.Characteristics of Community-based Housing Development and its Contribution to Poverty Alleviation. Ministry of Higher Education

8. A. Bebbington (1999) Capitals and Capabilities: A Framework for Analyzing Peasant Viability, Rural Livelihoods and Poverty World Development Vol. 27, No. 12, pp. 2021 $\pm 2044,1999$

9. C. Ashley and D. Carney. 1999. Sustainable livelihoods: Lessons from early experience Peasant Viability, Rural Livelihoods and Poverty World Development Vol. 27, No. 12, pp. 2021 $\pm 2044,1999$

10. A. Chimhowu and D. Hulme (2006). Livelihood Dynamics in Planned and Spontaneous Resettlement in Zimbabwe: Converging and Vulnerable. World Development, Vol. 34, No. 4, pp. 728-750, 2006_ 2006 Elsevier Ltd. All rights reserved. Department for International Development 1999

11.F. Ellis (2000), Rural Livelihood and Diversity in Developing Countries. Oxford publisher

12. I. Scones (1998) Sustainable Rural Livelihoods: A Framework for Analysis, IDS Working Paper 72, Brighton: IDS.

13. UNDP's (1999) Sustainable Livelihoods Diamond. 